\title{
Nepali Intellectuals in Exile: The History of Nepali Printing in 19th- and 2oth-Century Benares
}

\author{
Alaka Atreya Chudal | ORCID: 0000-0002-7308-7384 \\ Department of South Asian, Tibetan and Buddhist Studies, University of \\ Vienna, Vienna, Austria \\ alaka.chudal@univie.ac.at
}

\begin{abstract}
Restrictions on the freedom of speech and press, along with the unavailability of competitive printing solutions in Nepal under the Rana regime, caused the centre of gravity of scholarly activities to shift to India. A number of Nepali intellectuals, who came from a variety of backgrounds and had various reasons for having migrated to India, were involved in writing and publishing starting by the end of the 19th century. In those days Benares had few if any peers among Indian cities as a centre of local traditions of education and Sanskrit learning, and as a spiritual, economic and literary destination for Nepalis. Benares, which occupies a special place in Nepali history for its immense contribution to the country's cultural, social, literary and political evolution, was also the main hub of Nepali print entrepreneurs. This article will delve into early such entrepreneurs and an array of Nepali printing activities in Benares before 1950.
\end{abstract}

\section{Keywords}

print history - Nepali print history - Nepali intellectuals in the 19th and 2oth centuries Nepalis in Benares - Nepali migration to India

\section{Introductory Remarks}

Nepal has a long and prestigious tradition of Sanskrit scholarship. Much like India, it too has a tradition of learned Hindus from the earliest historic period. Intellectual activities spanned the fields of philosophy, literature, linguistics, astrology, tantra, astronomy, Ayurveda etc. Among evidence for this is a rich 
store of Sanskrit manuscripts, including Buddhist ones, that accumulated within a scribal culture of copying texts in different scripts, and have continued to be the focus of scholarship in vernacular languages. The initial period of Nepali literature was, it can be said, taken up with the translation of Sanskrit texts into Nepali or their reproduction. ${ }^{1}$ Religious, mythological, literary and moral Sanskrit writings were the ones mainly rendered into Nepali. Later this activity was enhanced by commentarial and further translational activities, but was only slowly supplemented by other types of literature. When in the 19th and 2oth centuries the neighbouring country of India, and the wider world beyond, was awakening to a rapidly expanding print market in vernaculars, print media were unable to tap into public interest in Nepal. Restrictions on the freedom of speech and press, along with the unavailability of cheap printing solutions in Nepal under the Rana regime, caused the centre of gravity of scholarly activities to shift to India. Indeed, the first printed Nepali book, Buddhi cānak, ${ }^{2}$ was published in Benares in $1875 / 76 .{ }^{3}$ A number of Nepali intellectuals were involved in writing, publishing and printing in India starting in the 19th century, mainly in the big cities of Benares, Bombay and Calcutta.

Against this backdrop, this paper will explore how Nepalis' involvement in printing got started in the 19th century. The end of Rana rule attracted many of them back to Nepal, where they hoped to find new freedoms and opportunities. This article will limit its study, therefore, to the period prior to 195o. It will focus on the Indian city of Benares, which was the main hub of Nepali print entrepreneurs. The attempt will be made to answer questions such as: Who was involved in the publishing business? What made Nepalis go to India and engage in the printing business? What kinds of books were published in and outside of Nepal during the first Nepali printing ventures? How did Nepalis react to the newly developed print culture? What were the popular books and genres it came out with?

As its main sources, this paper has used various catalogues, records, and databases, such as the catalogue of printed books from India and Nepal compiled by the British Library and the British Museum, the online catalogue of

1 Dayāāām Śreșțha, "Prārambhik kālko nepālī sāhityako pūrvapīṭhikā," in Jagadambā nepālī sāhityako brihat itihās: lok sāhitya, prārambhik kāl ra anuvād, vol. 2, ed. by Mādhav Prasad Pokhrel (Lalitpur: Kamalmanii Prakāśan, 2076 v.s.*), 379-662.

*Books and journals published in Nepal are generally dated (and here cited) according to the Vikram Samvat (v.s.) era, which is (depending on the month) 56 or 57 years ahead of the Common Era.

2 A reproduction of the Sanskrit text of the Cānakya niti ('Ethics of Chanakya').

3 Śaradcandra Śarmā Bhaț̣arāī, Ramā Śarmā and Śiva Regmī, Motirām Bhațta ra samssargī kavi (Kathmandu: Nepāl rājakīya prajñā pratișțhān, 206o v.s.), 5 . 
Madan Puraskar Library and the catalogues of print entrepreneurs in Benares. Other materials were collected, and interviews held, during my fieldwork in Benares and Kathmandu, and personal correspondence was carried on. This article is not a text-based study of either printed books or manuscripts; rather, it is simply a detailed examination of the history of Nepali print media and print entrepreneurs in Benares.

\section{Movement of Nepalis to Benares}

Kāśī, the classical name of Vārānasaì or Benares, occupies a special place in Nepali history for its immense contribution to the country's cultural, social, and political evolution. It has remained not only a religious but also an educational centre for Nepalis up into the 21st century. A famous Nepali proverb acknowledges the city's long history of erudition: vidyā harāe kāsí jānu, nyāya napāe gorkhā jānu ("If knowledge is lost, go to Benares; if justice is not obtained, go to Gorkha"4). Benares, which from the beginning was a popular destination for pilgrims and those seeking a Sanskrit education, later became a magnet for Nepalis for other reasons.

For Hindus who lived in what is now Nepal, Kāsisi was an important pilgrimage town from the first century on, but the earliest documentary evidence of such pilgrims is a 1576 inscription found in Patan's Tum Bahil telling of a noble called Lun Bhāro who performed a homa (fire sacrifice) in the Siddheśvar temple in Kāśì and who established a statue of Umā Maheśvara in memory of his grandson Dev Bhāro in the year 1574/75. ${ }^{5}$ The Malla kings of Nepal also undertook pilgrimages to Kāśi. The king of Patan Siddhinarsimha Malla, having enthroned his son, set off for Kāśi in 1652. It was the home in exile of the defeated king of Bhaktapur Ranajit Malla (1722-69), who died there. Later King Prithvi Narayan travelled there in the mid-18th century and performed tīrthaśrāddha, khadgasiddhi, pañcakośí yātrā and other religious rituals before setting out to unify Nepal. His grandson Rana Bahadur Shah was exiled to Benares and lived there as a yogi for five years under the name Nirgunānanda. In 1843 a temple was built by King Rajendra Bikram Shah and the crown prince Surendra Bikram Shah in the name of the senior queen Samrajya Lakshmi Devi in Lalitā Ghāt. The temple is known as the Nepali temple or Sāmrājyeśvar Mahādev Mandir. By the end of 18th century, when the number of Nepali

4 This famous proverb goes back to King Prithvi Narayan Shah.

5 Dhanavajra Bajrācārya, Madhyakālkā abhilekh (Kathmandu: Nepāl ra eśiyālī anusandhān kendra, 2056 v.s.), 35-37. 
pilgrims had started to increase, the Nepal government chose local priests, providing them with an officially stamped appointment letter (called a lälmohar) to serve as priests to the Nepali pilgrims. The successors of such priests are still known as lālmohariyā paṇ̣̂̄s. ${ }^{6}$

There was a tradition among Nepali Hindus, mostly ones with good financial resources, to spend the last years of their lives in Benares, where they wished to be cremated at the Manikarnikā Ghāt on the banks of the Ganga-a custom known as kāsisivās or kalpavāas ('dwelling in Kāsi until death'), and this, too, swelled the ranks of Nepalis there. Kãsíva $\bar{a} s$ could be either a matter of choice or of compulsion. In v.s. 1826 , after Bhaktapur was subjected to Shah rule, its king, Ranajit Malla, left for India of his own free will. Another king, Hemkarṇa Sen of Makwanpur, also willingly undertook kāśīiās (Nepāl 2018). Royals or other wealthy people typically took helpers and other family members along. The temples and two Nepali dharmaśälās ${ }^{7}$ ('rest-houses') built before $195^{\circ}$ confirm Kāsisis status as a place of pilgrimage for Nepalis from all walks of life.

The various restrictions, including limiting rights and relegation, continued during the Rana rule in Nepal, and the city of Benares remained one of the closest and most attractive destinations of expatriates. Those who went there did so mainly for political, religious or educational reasons, and to some extent for economic ones as well. The migrant Nepalis worked there in the hotels, as guards or watchmen, priests, proofreaders, publishers and teachers.

Many Nepalis went to Kāsī for education, but we do not have any firm date when this tradition started. Long before the British arrived, Kāśi was a centre of learning. Travellers' reports from the mid-17th century testify that there were pāthśálās (institutions of learning) attached to some of the larger

6 For more on Nepalis in Benares see:

Alakā Ātreya Cūdāl, "Nepali sāhityako itihāsmā Kaśî," In Uttarbhāratko nepālī sāhityako itihās, ed. by Alakā Ātreya Cūdāl, In Jagadambā nepālī sāhityako brhat itihās, vol. 3, ed. by Mādhav Prasād Pokhrel (Lalitpur: Kamalmaṇi Prakāśan, 2077 v.s.). Martin Gaenszle, "Nepali Places: Appropriations of Space in Banaras," in Visualising Spaces in Banaras: Images, Maps, and the Practice of Representation, ed. by Martin Gaenszle and Jörg Gengnagel (Wiesbaden: Harrassowitz Verlag, 2006), 303-24. Martin Gaenszle, "Emergent Nationalism, Citizenship, and Belonging among Nepalis in Banaras: The Case of Kashi Bahadur Shrestha," in The Politics of Belonging in the Himalayas: Local Attachments and Boundary Dynamics, ed. by Joanna Pfaff-Czarnecka and Gérard Toffin (New Delhi: SAGE Publications India Pvt. Ltd., 2011), 20121. Martin Gaenszle, (in collaboration with Nutan Dhar Sharma), "Nepali Kings and Kāśî: On the Changing Significance of a Sacred Centre," Studies on Nepali History and Society 7, 1 (2002): 1-33. Rhoderick Chalmers, "We Nepalis': Language, Literature and the Formation of a Nepali Public Sphere in India, 1914-40." Ph.D. thesis (soAs, University of London, 2003).

7 One was in Lalitā Ghāț and the other in Mangalā Gauri (the latter established at the instigation of the intellectual Jagannāth Gurāgãã in 1943 together with a Sanskrit student hostel). 
temples. These pāthśālās along with tuition in the private houses of learned pandits were financed and supported by wealthy merchants. ${ }^{8}$ Later this tradition was also established in various places in Nepal. ${ }^{9}$ The students of such pāthśa āa s would go to Benares for the final exam, as there were no authenticating institutions to provide certificates in Nepal. In 1899 the Rana government started providing monthly a five-rupee stipend to students going to Kāśī for Sanskrit studies. By 1946 this stipend had risen to Rs. 50 for travel to and from Benares, accommodations and food for the period of exams. ${ }^{10}$ Besides the existence of such pāthśâlās, there is much other evidence of Nepalis going to Kāsi i for education. Starting with the famous early writers and scholars Bhanubhakta Acharya and Motiram Bhatta, there are a host of Nepalis who studied in Benares. For example, Shiromani Acharya Dixit (1824-1903) studied in Kâsî̀ until he was nineteen with the pandits Amshumali Pandit, Kashinath Shastri, Nrisimha Shastri and Jayaram Shastri. ${ }^{11}$ Other Nepali scholars including the royal priest Hemraj Sharma and Ram Mani Acharya Dixit studied in Kāsī with the pandit Gangadhar Shastri. ${ }^{12}$ We can say that up until 1950 most Nepali scholars and educated population were the products of Benares. When in 1915 Madan Mohan Malaviya established Benares Hindu University, even more Nepalis were attracted to the city, where they typically studied English, medicine or engineering.

8 Vasudha Dalmia, "Sanskrit Scholars and Pandits of the Old School: The Benares Sanskrit College and the Constitution of Authority in the Late Nineteenth Century," in Journal of Indian Philosophy 24 (1996): 322.

9 Some early Sanskrit pāthśâlās are the following:

1. Nārāyaṇhiṭī Saṃskṛt Pāṭhśālā, Kathmandu, estd. circa 1870 by the Rana government; first teachers: Nildev Panta, Vacaspati Panta

2. Saṃskṛt Pāṭhśālā, estd. 1875 in Bhojpur by Ṣaḍānanda Adhikari

3. Harihar Pāthśāāā, estd. 1937-38 in Arghakhachi; financed and supported by Harihar Gautam; taught by Dadhiram Marasini

4. Rānī Pokharī Saṃskṛt Pāțhśālā, estd. 1877 in Kathamndu by the Rana government

5. Saṃskṛt Pāțhśálā, estd. 1909 in Janakpur

6. Rị̣ī Saṃskṛt Pāțhśālā, estd. 1909 in Gulmi (personal communication).

10 Students demanded an increment in the stipend to Rs. 100 per person, but Hemraj Sharma proposed even lesser amount, Rs. 25 rupees per student. The decision taken was one of the reasons for the anti-Rana agitation among Sanskrit students, famous as the jayatu saṃskrtam āndolan. See Bhuphari Paudel, Nepalko vidvatparamparā (Kathmandu: Nepālī Sāhitya Prakāśan Kendra, 2051 v.s.), 8.

11 Keśavmaṇi Ā. Dīkṣit, Śiromaṇi ācārya dīkșit (Kathmandu: Śāntiniketan Pustakālaya, 2072 v.s.), 12.

12 Vyākul Pāțhak, Nepālkā viśvakoṣ (Kathmandu: Vidvacchiromaṇi hemrāj puraskār guṭhī, 2015), 40; and Ghațrāj Bhaț̣arāi, Pratibhaipratibhā ra nepālè sāhitya (Kathmandu: Ekata Books, 2051 v.s.), 68. 
The Nepali population before 1950 mainly occupied the old part of town, the locality in the area around Rām Ghāt, Mangalāgaurī, Dūdhvināyak, Brahmāghāṭ and Pañcagangā Ghāț. There were many who purchased houses with the idea of staying permanently. In the early 20 th century there were probably some 5 o private houses in the old city of Benares owned by Nepalis, ${ }^{13}$ but many were sold off at cheap prices later, most of them apparently after Indian independence. ${ }^{14}$

\section{Nepali Intellectuals in Exile: Activities of Nepali Intellectuals in Benares}

It is clear that the majority of travel to Benares had to do with pilgrimages, education or exile. Students and exiled intellectuals involved themselves in the literary and publication fields. Such literary activity played a crucial role in the making of Nepali literature-in the turn from the initial phase (prāthamik kāl) to the middle phase (mādhyamik kāl) —and in the early publication of that literature. Below we concentrate on various intellectual activities, such as writing, the encouraging of writing and the publication of writings. First, though, we shall discuss exiled Nepali print entrepreneurs in Benares before 1950, for which purpose it will be good to learn how the situation arose in the first place.

\section{The Emergence of Nepali Printing in Benares}

Ulrike Stark, ${ }^{15}$ in exploring the history of printing in Benares, argues that given its religious and economic importance as a pilgrimage site, the excellence of its Hindu scholarship, its well-established patronage structure and vibrant cultural life, Benares was predestined to become a printing centre for publications in Sanskrit and Hindi, the languages most associated with Hindu culture. It was in fact the first Indian city to gain importance in non-educational Sanskrit and Hindi publishing. Early printing shops sprang up in the city in

13 Some of the house owners: Colonel Hemdal Thapa (who accompanied the expelled queen Rājya Lakșmī to Benares and bought his house in 1840), Dev Shamsher Rana (residing approximately from 1901 to 1950), Pundit Hemraj Sharma (who was gifted a house at Rathyātrā Caumuhānī by the youngest mahārānı̄ of Prime Minister Chandra Shamsher in 1939), Shiromani Acharya Dixit (in Ramkațorā).

Source: Alaka Atreya Chudal, A Freethinking Cultural Nationalist: A Life History of Rahul Sankrityayan (Delhi: Oxford University Press, 2016) \& Gaenszle, Nepali Places, and personal communication.

14 Gaenszle, Nepali Places, 319.

15 Ulrike Stark, An Empire of Books: The Novel Kishore Press and the Diffusion of the Private Word in Colonial India (New Delhi: Permanent Black, 2007), 59. 
the mid-184os, but it was only after 1857 that commercial presses there started surviving on Hindi printing alone, in spite of the fact that the bulk of book printing was still in Persian and Urdu.

When in the second half of the 19th century many Nepali intellectualswhether by their own wish or forced to do so-took up residence in Benares, by then a centre of education and printing, some of them threw themselves into writing or publishing. Most of the Nepali books published in India were published there. It was mainly students and politically exiled intellectuals who tended to be attracted to the business, more so than members of other professions, inasmuch as they felt at home in Sanskrit and Hindi. Many, of course, also engaged in more menial labour at printing presses for their living. Motiram Bhatta for one worked for Ram Krishna Varma's Bharat Jivan magazine in Benares, ${ }^{16}$ and it could be argued that this work experience was what launched his later career in publishing Nepali literary works and in encouraging Nepalis to write and seek publication. He succeeded in publishing Bhanubhakta Acharya's Rāmāyaṇa in September 1887 (considered the first home-grown work printed in Nepali), the Jiv an Caritra (Bhanubhakta Acharya's life story) in 1891 and several of his own poems in the intervening years. ${ }^{17}$ Other Nepalis earned their living by writing or proofreading for publishers. After he lost his business, Kashi Bahadur Shrestha remained in Benares and turned to editing and proofreading. ${ }^{18}$ These examples suggest that printing was a profitable business, and indeed gradually more and more expatriate Nepalis became interested in it.

The Indian independence movement, the emerging print culture, linguistic and literary consciousness, and the rising sense of nationalism made big impressions on the suppressed Nepali community back home. Such new forms of political and linguistic (especially vernacular) awareness among them took their lead from Indian developments. The Nepali language became the lingua franca of the multilingual Nepali community and a symbol of jāti (a single caste, the Nepali community), and this paved the way for the rapid spread of both the language and its literature. ${ }^{19}$

The Nepali intellectuals involved in the book trade were in truth print entrepreneurs more than actual publishers; they themselves did not own publishing houses. More specifically, they were in the mail order business. After the establishment of a good railway network and postal service in India, such

\footnotetext{
16 Durga Bahadur Shrestha, Kashi Bahadur Shrestha (Delhi: Sahitya Akademi, 2003), 58.

17 Michael Hutt, Nepali: A National Language and its Literature (New Delhi: Sterling Publication, 1988), 126.

18 Shrestha, Kashi Bahadur Shrestha, 17. The rate at the time for editing work was Rs. 5 for a crown size page and Rs. 6 for a demy size.

See Chalmers, 'We Nepalis'.
} 
businesses were in a position to prosper. The seller approached prospective buyers only through mail circulars, price lists and sales catalogues. Their businesses tended to focus on unbranded or small-scale goods, since such goods were available at lower costs through special contract arrangements with the manufacturers. The post office collected the amount due on the goods and remitted it to the seller or mail order house. ${ }^{20}$ The Nepali mail order entrepreneurs supplied such general consumer goods as yak tails, janais (sacred thread), turmeric powder, Nepali caps, Nāg Pañcamī posters, rāmnāmī shawls (shawls embroidered with Rama's name), Ayurvedic oils, and pañcāngas (astrologic calendars). The customers in the beginning were mainly soldiers of Gurkha regiments from the British Indian Army or the local police, or else Hindu pilgrims and Nepali migrants to India. ${ }^{21}$ Besides the normal goods, the entrepreneurs started including religious books along with a few romances and mildly erotic literature (śrngārik sāhitya) among their deliverable items. Once such reading material was introduced among the Nepalis, and among soldiers and students in particular, interest gained momentum, especially for the last genre. ${ }^{22}$

Books were sales tax-free commodities even in the mail order business, and that was one of the reasons why entrepreneurs slowly shifted offerings away from other goods and onto printed or reprinted titles to tap into a growing market. The publications catering for Nepalis were very reasonably priced. Some entrepreneurs personally visited army barracks and other areas populated by Nepalis with their goods (including books) in a bag and sold them there. Every imaginable item was available to meet demand. British Gurkha soldiers in the barracks and Nepalis serving as local police were a readily identifiable readership of erotic literature (laharī sahitya) ${ }^{23}$

\section{Nepali Print Entrepreneurs}

Most of the Nepali intellectuals involved in the book trade had been exiled. Most of them, too, did writing themselves, being well versed in Sanskrit, Nepali, and other languages. Rather than calling them publishers, I have used

20 Krishna Chander, Encyclopaedic Dictionary of Commerce, vol. 2. (Delhi: Sarup \& Sons, 1999).

21 "In 1900 the Indian Census recorded just under a quarter of a million people of declared Nepalese origin" (Hutt, Nepali, 142).

22 Sagar Sharma, personal communication.

23 Laharī, a style of poetry meant for singing or melodious recitation, is generally long, though some forms may be shorter. It was popularized by Nepali writers mainly as a vehicle of erotic poetry. 
the term "print entrepreneurs," given that they started in Benares with the aim of printing and/or selling any printed book as one of their commodities. In the following, the major Nepali print enterprises in Benares established before 1950, as identified on the basis of available sources, will be briefly introduced.

\section{The Gorkhā Pustakālaya / Viśvarāj Harihar ${ }^{24}$}

Two cousins, Vishvaraj Sharma (Lamichane) and Harihar Sharma (Lamichane), both born within a year of each other between 1862 and 1863, established a shop in Benares in 1881, initially to vend general consumer goods along with, on the side, Sanskrit texts and vernacular commentaries. Devaraj (Vishvaraj's cousin and Harihar's brother) joined them later. Their fathers Vishnuhari and Jivanath had been educated in Benares. Later Vishnuhari settled in Benares and Jivanath moved to Kathmandu. They belonged to a learned family. The family also had printing experience in Nepal. (Vishvaraj's elder brother Dhanaraj had established the Chandra Prabha Litho Press in Kathmandu, and may have had working experience at the Bhagavati Press.) The bookshop the two cousins established in Benares was called the Gorkhā Pustakālaya. Their first collaborative output was the Pārvan śrāddhavidhi, edited by Harihar, published by Devaraj, and printed at the Brajacandra Yantrālaya in Benares in $1884 / 85$, followed by the Svasthānī vratakathā in $1885 / 86$ and the Śloka pañcāsikā in 1887/88 from Allahabad's Prayag Press. Books were published sometimes under Harihar Sharma's name alone, and sometimes under the joint names Devaraj-Harihar or Vishvaraj-Harihar. In 1893/94 the Gorkhā Pustakālaya set up its own Durgā Press. Vishvaraj and Harihar were the first successful Nepalis in this business, and their Gorkhā Pustakālaya expanded to Calcutta in 1907, with Divakar Sharma coming in as manager in ca. 1922. Already sometime around 1885 they started making good on a commitment to bring out original Nepali works. It is said that they published the highest number of Nepali books outside Nepal. Later, when the business slowed down and they were left without a male inheritor, their books were published under other names (e.g. Shiva Prasad Raghoram, who was something of an adopted son of Vishvaraj).

\section{Gorkha Yanträlaya ${ }^{25}$}

Damaruvallabh Pokhrel fled from Kathmandu in 1888 to Benares after coming under political fire, the circumstances not being exactly clear. In the Indian city he established a press called the Gorkha Yantralaya. Probably his first

24 Sources: Chalmers, 'We Nepalis'; Bhațțarāī, Pratibhaipratibhā ra nepālı̄ sāhitya; Bhaț̣arāī et al., Motirām Bhațta, and Kamal Dixit (personal correspondence).

25 Source: Bhațtarāī et al., Motirām Bhaț̣a. 
published book was Raghunath Pokhrel's Sundarkāṇda. His publications were not allowed to be imported into Nepal, given the cloud hanging over him. The consumers of them were largely Gurkha soldiers. In 1885 he had jointly published with Devaraj Lamichane (from the Gorkhā Pustakālaya) Bhanubhakta Acharya's Rāmāyana, and by July 1887 had also begun printing the first Nepali weekly, the Gorkhā samcār patra. Damaruvallabh was more a publisher than a writer, but he was well versed in Sanskrit and left some verses as evidence of his writing skills.

\section{Subba Homnath Kedarnath ${ }^{26}$}

Homnath Upadhyaya Khatiwada $\left(1854 / 55^{-1927 / 28)}\right.$ was Crown Prince Trailokya Vikram's 'milk brother' (i.e. the son of his wet-nurse). He entered palace service in Kathmandu after his education and attained the rank of subba. ${ }^{27}$ He had a son named Kedarnath (1878/79-1946/47), and in 1881/82, when the boy was just three years old, he and his brother Tanka Prasad together with eight other Brahmins were exiled to India. ${ }^{28}$ There, in Benares, he continued to be involved in political schemes, but once he realized that it was not possible to overthrow the Rana government from a foreign country, he turned to the mail order and publishing business, ${ }^{29}$ and established a concern in the joint name of father and son with the addition of his title (Subba Homnath Kedarnath), while his brother went on to establish the Hitaishi Company in Calcutta in 1886. Kedarnath worked in his father's company and eventually became its manager. The Homnath Kedarnath publishing house emerged as one of the most successful of the Benares-based Nepali ones. ${ }^{30}$ The father was himself a successful writer, but is known for having suppressed authors' names and

26 Sources: Chalmers 'We Nepalis'; Bhațțarāi, Pratibhaipratibhā ra nepālı̄ sāhitya.

27 A title for a high-ranking official in the Rana government.

28 The circumstances were as follows: Commander-in-Chief Dhir Shamsher was the most powerful figure during the regime of Rana Prime Minister Ranoddip Singh Rana (a brother of Jang Bahadur Rana senior in rank to Dhir). Crown Prince Trailokya married three daughters of Jang Bahadur, and he colluded with a son of Jang Bahadur, Jagat Jang, to ensure that they both would come into power after Jang Bahadur's death, but Dhir Shamsher foiled the plot, and Trailokya was killed under suspicious circumstances. A few years later the secret came out, the culprits were punished, other fellow caste members were killed, and the ten Brahmins alluded to here had their heads shaved into four parts, after which they were paraded about the city, excommunicated from their caste and exiled.

29 In an advertisement of one of his publications (Śrngāra-darpaṇ 1928) he describes himself as "the king of verse books that have now been in circulation for forty years," which means that he had been publishing since ca. 1888 .

Kamal Dixit (personal communication). 
having published others' books as his own writing. He later owned his own press, called the Hitaishi Press, but when he realized that printing on other presses was cheaper, he gave it up. The son, too, was a noted writer in his own right.

\section{The Prabhakari Company ${ }^{31}$}

In 1898/99, Shiromani Acharya Dixit performed a soma yagya in his own house in the Ramkatora quarter of Benares. Afterwards his five sons (Damodar, Kashinath, Sadashiva, Ramchandra and Harihar) jointly established a publishing house there, the Prabhakari Company, with the aim of publishing Sanskrit books. Later they also added their own press, called the Prabhakari Press/Yantralaya. The eldest son took chief responsibility in the beginning, but he inclined more to spiritual interests, and so turned over charge of operations to his youngest brother Harihar. But Harihar Acharya had no better luck with the business in Benares and shifted to Bombay, there establishing his own publishing company, the Gorkha Pracharak Mandal, which did not survive for long. Back in Benares, the Prabhakari Company was still floundering. Kashinath's son Ram Mani was sent for from Kathmandu to salvage operations in November 1903. He worked very hard for almost six years and the situation improved markedly. Besides Sanskrit and Hindi books, he also started printing Nepali ones along with a magazine, Mādhavi, with the aim of encouraging prose writing in his mother tongue. Witnessing the Hindi language movement in Benares, he felt inspired to try to similarly uplift his own language, and so devoted himself to bringing out Nepali publications and standardizing or otherwise improving Nepali prose. A branch office was established in the Gyanvapi section of the city to improve operations. The company now took up the mail order business, which was becoming popular among Nepali print entrepreneurs, and this proved to be a beneficial step for the company. Unfortunately, the Rana government felt his activities in India posed a threat, and he was called back to Kathmandu in August 1909, which put an end to both the company and the magazine.

\section{Dhundhiraj Rishikesh ${ }^{32}$}

Dhundhiraj Rishikesh was a company run by two Nepali Brahmins, Dhundhiraj (surname unknown) and Rishikesh Upadhyaya. A businessman, Nani Babu

31 Source: Rāmmaṇi Ācārya Dīkṣit, Purānā saṃjhanā, ed. by Keshar Mani Acharya Dixit (Kathamndu: Nalini Devi Acharya Dixit, 2029 v.s.); Dīkșit, Śiromaṇi ācārya dīkṣit.

32 Sources: Bhațtarāi, Pratibhaipratibhā ra nepālù sāhitya; Madan Puraskar Pustakalaya catalogue; Kamal Dixit (personal communication). 
Subba, gave Dhundhiraj money to establish a conventional business, but Dhundhiraj invested the money instead in a publishing house. He seems to have done so jointly with Rishikesh Upadhyaya, with whom he published a number of books. The Madan Puraskar Pustakalaya database shows seven books published under their joint name between v.s. 1956 and v.s. 2012. Later Sadashiva Sharma (v.s. 1931-2003) joined the mail order business. He was the son-in-law of another publisher, Harihar Sharma, and therefore spent most of his time in Benares. He had been doing writing in Nepali and working at the Lahari Press under the Hindi writer Devakinandan Khatri, two of whose popular Hindi novels, Candrakāntā (part one) and Narendra mohinī, he translated into Nepali. To protect himself from any association with a fire incident in Balwa, ${ }^{33}$ and the investigation of it, Shadashiva Sharma wrote under the name S.S. Sharma. Dhundhiraj Rishikesh again mainly published religious books. Its most prominent publication is Kulachandra Gautam's Nepali commentary on the Amarakośa in three volumes, brought out in v.s. 1956.

\section{The Nepali Pustakalaya ${ }^{34}$}

Shikharnath Sharma Subedi shifted to Benares in 1900/o1, after Shiromani Acharya Dixit had entered upon kāsívās, and remained there for the rest of his life. His poetry, written in a very easily understood language, attracted a substantial readership, which inspired him to establish a publishing business and bring out his own works. He also opened a bookshop, the Nepali Pustakayaya. This business was enough to keep him going. On the title page of his $A$ kșarmāla ('A garland of alphabetical letters', 1913) he highlights his own multiple talents as "a writer, a compiler, and a publisher [of thirteen heterogeneous books]."

\section{Krishna Madhav \& Co. (Later: Babu Madhav Prasad Sharma $)^{35}$}

Krishna Prasada Koirala was a successful businessman and social worker from Biratnagar, Nepal. He used to visit Calcutta very frequently on business and stayed abreast of developments there. His progressive nature, reflected in his

33 Sadashiva Sharma's father Kulchudamani Sharma was appointed deputy head of the Balwa court in Mahottari, in the southern part of Nepal. The family lived in Balwa, but Sadashiva Sharma most of the time stayed in Benares near his in-laws. When the court was devastated by fire, the whole family went to Benares, knowing that the staff of government offices could be detained indefinitely for questioning when such incidents occurred during that period in Nepal. Kulachudamani left his family in the hands of Sadashiva and fled even further away to Assam. He was later cleared of all fault for the fire, and Sadashiva Sharma eventually returned to find a job in a post office in Kathmandu.

34 Sources: Chalmers, 'We Nepalis'; Bhațțarāi, Pratibhaipratibhā ra nepālē sāhitya.

35 Sources: Viśveśvarprasād Koirālā, Ātmavrttānta (Kathmandu: Jagadambā Prakāśan, 2068 v.s.); Ila Sharma (personal communication). 
wish to establish schools and hospitals, was a thorn in the side of the Ranas. During Chandra Shamsher's rule, he was exiled from his hometown along with 45 others and settled down in Benares, where he rented a house with more than twenty rooms. Madhav Prasad Sharma (Regmi) and he established a publishing firm and named it Krishna Madhav \& Co., which they ran jointly between 1920 and 1923. Later Krishna Prasad Koirala left it, and the name was changed to Babu Madhav Prasad Sharma. Madhav Prasad Sharma also ran a mail order business and imported turmeric powder from Nepal for sale in India. When he died, his wife Krishna Kumari took over the business and concentrated more on books. The record of Madhav Prasad Sharma's publications starts from 1923 with Khädo jagāune kavitā ('A sword ceremony poem') and moves on to Jarman laḍā̄ ko savāi ('A savā $\vec{\iota}^{36}$ [poem on] the German war', 1926), written by Rajvir Rai. This is among the very few Nepali print entrepreneurs established before 195 o that still survive.

\section{Mahakali Aushadhalaya ${ }^{37}$}

Padma Prasad Upadhyaya established the Mahakali Aushadhalaya to sell medicine, and on the side engaged in book publication and distribution. He also ran a gambling den and brothel. Indeed he had all sorts of money-making schemes. His son Punya Prasad Upadhyaya later joined his father's publishing business and developed some writing skills of his own. Later, when they were looking around for a writer who could produce material on demand as well as manage publication, they enlisted the services of Shambhu Prasad Dhungyal, who had arrived in Benares in 1920/21 after being dismissed from his job and exiled by the Rana government on the grounds that he had written an introduction and poems for the controversial book Makaiko khetī by Subba Krishnalal. Shambhu Prasad's retellings of Akbar-Birbal stories were already being published in 1916 by Mahakali Aushadhalaya before he joined the company. After his arrival the business made impressive strides. But in ${ }_{1927}$ Padma Prasad found himself the accused in a court case, and that spelled the end of his ventures.

From the above brief description of major Nepali printing enterprises we gain some idea of how Nepali printing came to flourish in Benares. Among the Nepali entrepreneurs there, only the Prabhakari Company seems to have been established solely as a printing business, but later it too fell in line with the popular trend of taking mail orders. Other entrepreneurs pursued from the beginning the aim of supplying consumer goods along with books. Such

36 The name of a metre.

37 Source: Chalmers 'We Nepalis'. 
businesses were mostly family ones, which is another telling fact about the Nepali print entrepreneurs in India.

\section{Nepali Literary Activities in Benares}

Nepali literary activities and the Hindi literary scene in India in the 2oth century developed along very similar lines. Inspired by what was going on in Benares, Nepali intellectuals engaged wholeheartedly in literary and other language-related activities. It is worth considering Ram Mani Acharya Dixit's account ${ }^{38}$ of his own activities in the first decade of the 2oth century Benares:

There is no question but that the Indian independence movement had an influence on me. There is no question but that the feeling that I ought to do something for my country stirred me, too, awakening a desire to serve it and its people through service to language. In any case, I started to understand the state of the Nepali language. My heart wept at the dreadful state it was in at the time. I had no peace of mind, wondering day and night how to uplift the language, how to serve it. I didn't have a lot of patience. I wanted to lay hand to everything at once. ${ }^{39}$

The most notable early steps in literary and publishing activities in Nepali were those taken by Motiram Bhatta (1866-96). After coming to Benares for the second time in around 1881, he was introduced to Bharatendu Harischandra and a few times visited poetry meetings centred on samasyāpürtis. Samasyāpürtis were an old poetic tradition involving riddles or improvised verse that was to end with a given line, a form of competition in early Indian palaces during which kings would bestow rewards. It is said that Motiram Bhatta received ten rupees from Bharatendu Harishchandra as a prize for his solution to a samasyāpūrti in a poetic meeting organized at the latter's home. Inspired by such kavitāvardhinī sabhās ('meetings promoting poetry'), Motiram Bhatta

38 Dīkṣit, Purānā saṃjhanā, 8 .

39 Bhäratīya svatantratā āndolanko mamā chāp pareko hunū paradacha. Tesle malāì panì deśko nimitta kehī garū bhanane bh dèśakō nimitta kēhī garũ bhananē bhāvanālè ghacaghacāera bhāṣāsēvābāta dēśr ra dèśvāsīkō sēvā garanē icchā paidā bhaēkō hunuparadacha. jē hōs nēpālè bhāṣākō avasthā bujhna thālẽ. tyō bēlākō nēpālè bhāṣākō duravasthālē dil rōyō / katābāța kasarī bhāṣākō uddhār garũ, sèvā garũ, bhananē kurālē din rāt pīralna thālyō. tetī dhairya thiena. cāraitira ekaicoți hāt hàlna man lāgyo. 
himself created a group of poets in Benares called the Samasyāpūrti-maṇạalī ('Poetic Riddle Circle'), which included Padmavilas Panta, Kashinath, Ranganath (last names not known), Tejbahadur Rana, and Chet Singh. He believed that erotic or romantic topics would easily attract interest, so he proposed focusing on them and starting off by approaching them through samasyāpürtis. ${ }^{40}$ This strategy worked, as reflected in rapidly increasing numbers of publications. After going back to Nepal in around 1888, Motiram Bhatta created a similar group of poets there and opened a bookshop, the Motikṛṣna Dhīrendra Kampanī, together with friends. This is how a new era in Nepali literature, the middle period (mādhyamik kāl), started.

\section{Book Publication}

Print entrepreneurs invested ever more money in their ventures, and śrngārik sāhitya was one of the important triggering elements in their rise. Meanwhile, back in Nepal, the Ranas' courtly life also revolved around the poetic and musical. Their prime ministers occasionally invited musicians and singers from India to entertain them, and their taste for śrnggāra poetry, in particular, further encouraged authors to write about such subjects. The Urdu gazal and thumri metres were adopted by many Nepali poets of the period. ${ }^{41}$ Still, the Rana palace shut down the literary magazine Sükti sindu (1917), published in Kathmandu, accusing it of being vulgar and misleading youth. It was also banned from being read. This action on the part of the government marked the turning point in the history of Nepali literature from an era focused on the erotic (śrngāra) to the (parișkārvād) classical era. However, the former flourished further in India. Erotic verse also continued to be commonly smuggled into the Rana palaces, where it was avidly consumed by the many isolated female servants of the household ${ }^{42}$ (many of whom were literate, especially ones engaged in the palace theatre productions).

During this period lahari poetry had been entering the Nepali literary realm-most of it from India, particularly from Benares-and securing a place for itself within the romantic/erotic genre. Annanda Laharī, Prem Laharī and Madan Lahari were bestsellers of the period. Much of popular romantic lahari poetry features narratives about lahures (Gurkha soldiers in the British Indian Army) and the life they led. Besides erotic and religious literature,

\footnotetext{
$40 \quad$ Bhațțarāī et al., Motirām Bhațta, 8.

41 Hutt, Nepali, 126.

42 Chalmers, 'We Nepalis', 49, Sagar Sharma (personal communication).
} 
the Nepali print entrepreneurs were interested in publishing folk tales based on such stories as found in the Vìrsikkā, Lälhirāa, Madhumālati, Betāl Paccīsī, Siṃhāsanbattīsī, Hātimtī, Gulbakavali, Gulsanovar and Hitopadeśa. Going back to Hindi, Sanskrit, Arabic and Farsi sources, these books attracted a huge Nepali-based readership, particularly among literate non-scholars or young students who read to be entertained. The religious texts that formed the basis of traditional Sanskrit education or karmakānda also sold quickly. This is how book printing and Nepali involvement in it and in the book-selling business came to flourish in Benares.

Many early Nepali publications were paraphrases of original Sanskrit texts, a majority of which were Puranas. The practice of paraphrasing went back to what is known as bhāvapadyānuvāda ('a paraphrased poetic rendering'). Inasmuch as the target groups of print entrepreneurs were mainly religious pilgrims, Sanskrit students who performed religious rituals for Nepali pilgrims, religious devotees in Nepal and Gorkha soldiers (and other consumers of erotic and folk tales), it was karmakañda, pañcānga (astrological manuals, almanacs with dates according to the Hindu astrological calendar), astrology-related titles, erotic literature in the mould of laharisähitya and folk tales that were the most highly in demand in the market. Rhoderick Chalmers ${ }^{43}$ has described in detail the popular nature of Nepali publishing in Benares, including the many mildly erotic poems and other popular books that were affordably priced. Still, as most of the entrepreneurs had had a Sanskrit education, they also showed interest in printing translations of Sanskrit texts or commentaries on them.

\section{Literary Journals}

Literary journal publication and journal writing was also considered service to the mother tongue, and thus to the nation, in the first half of the 2oth century in Benares. Readers, writers or publishers as a whole shared this sentiment, as did Nepali journalists. The Nepali literary journals or newspapers and their editors published in Benares before 1950 are as follows: ${ }^{44}$

43 Rhoderick. Chalmers, "Pandits and Pulp Fiction: Popular Publishing and the Birth of Nepali Print Capitalism in Benares." Studies in Nepali History and Society 7, 1 (2002): 35-97.

44 Sources: Pārasmaṇi Pradhān, "Kāśīko nepālī bhāṣā," Vāṇ̂̄ Sādhanā 2-3, nos. 2-3 (2039-40 v.s.): 2-3.; Chalmers, 'We Nepalis'; Sādhanā Pratīkṣā, "Mādhyamik kālko patrapatrikāko itihās," in Jagadambā nepālì sāhityako brihat itihās: lok sāhitya, prārambhik kāl ra anuvād, vol. 2, ed. by Mādhav Prasad Pokhrel (Lalitpur: Kamalmaṇi Prakāśan, 2076 v.s.), 787-815; Bhațțarāī et al., Motirām Bhaț̣a; Cūdāl, "Nepali sāhityako itihāsmā Kaśí." 


\begin{tabular}{|c|c|c|}
\hline Year & Name & Editor \\
\hline 1886 & Gorkhā Bhārat jīvan (monthly) & Motiram Bhatta \\
\hline 1886 & Gorkhā samācār patra (weekly) & Damaruvallabh Pokhrel \\
\hline 1902 & Upanyās tarañgiṇi (monthly) & Pt. Sadashiva Sharma \\
\hline 1904 & Sūkti sudhā (Sanskrit) & Bhavani Prasad Khativada \\
\hline 1905 & Kavitā kalpadrum & Durga Prasad Sharma Ghimire \\
\hline 1906 & Sundarī (monthly) & Rasik Samāj $^{45}$ \\
\hline 1908 & Mādhavī (monthly) & Matri Prasad Adhikari \\
\hline 1914 & Candra (monthly) & Madho Prasad \\
\hline 1915 & Gorkhālì (weekly) & Devi Prasad Sapkota \\
\hline 1922 & Janmabhūmi (monthly) & Surya Vikram Gyawali \\
\hline 1926 & Rājbhakti (weekly) & Shambhu Prasad Dhungel \\
\hline 1936 & Udaya (monthly) & Kashi Bahadur Shrestha \\
\hline 1940 & Sarva Hitaiși (monthly) & Chavilal Acharya \\
\hline 1946 & Puruṣārtha (monthly) & Buddhisagar \\
\hline 1947 & Yugvāṇī (weekly) & $\begin{array}{l}\text { Lakshmi Prasad Devkota, Narayan Prasad } \\
\text { Upadhyaya, Balchandra Sharma \& } \\
\text { Krishna Prasad Upadhyaya }\end{array}$ \\
\hline 1950 & Chātra (seasonal) & Bharat Mani Pradhan \\
\hline
\end{tabular}

The survival rate of such journals was not very long. Almost all journal editors were Nepalis who had migrated but lived in Benares only for a limited time. Therefore, their journals stopped publishing after they left. Some editors were students who, when they returned after completing their studies, closed down their journals (i.e. Chätra). The Nepali government was alert to Nepali journalistic activities in India and tried their best to control them. Some editors were called back to Nepal and had to stop publishing (e.g. Rammani Acharya Dixit, editor of $M \bar{a} d h a v \bar{\imath}) \cdot{ }^{46}$ Some journals, such as Gorkhālì, simply had to shut down. ${ }^{47}$ In most cases, though, the main hurdle was lack of financial backing.

$45 \quad$ A literary society of young Nepalis studying in Benares

46 As discussed above under the Prabhakari Company.

47 Gorkhālī was the first Nepali political weekly. Chandra Shamsher felt it could harm the Rana regime, and put a stop to it after two years. Another journal instantly sprang up with the aim of praising Chandra Shamsher; see Iśvar Barāl, Jhyālbāța (Lalitpur: Sajha Prakashan, 2053 v.s.), 90.

In Taranath Sharma's view, Gorkhälī was the first journal that aimed to stimulate Nepali pride, development and progress. The lack of customers, the greater interest in erotic literature and Nepali government's opposition to publications that raised awareness in 
Only one literary journal, Udaya, is still alive, and the reason for this is that its editor-cum-publisher has been a permanent resident of Benares, Durga Bahadur Shrestha, the son of its founder Kashi Bahadur Shrestha, having kept it going.

No copies of Gorkhā Bhärat jīvan and Gorkhā samācār patra are available anymore. Upanyās tarangini was started with the aim of publishing Nepali novels but it did not go beyond a couple of numbers. Sükti sudhā was a journal dedicated to Sanskrit poetry, and again did not survive very long. Some journals were published to toe the Rana government line (e.g. Rajjbhakti), while others had first to clarify that their aim was different from that of banned or discontinued journals (e.g. Janmabhümi), which in its first issue distanced itself from Gorkhäli. Candra, too, declared in its first issue that it would not publish anything against the English and Nepal governments; it nevertheless folded quickly. Yugvannī, a publication meant to raise political awareness among the public while also prioritizing literary material, survived only two years after political change came to Nepal in 1951.

\section{The Response to Printing in Nepal during the Rana Rule}

Although the first printing press was brought to Nepal during the rule of Prime Minister Jang Bahadur Rana and the publication committee Gorkhā Bhāṣā Prakāśinī Samiti was established in the period of Chandra Shamsher, these rulers did not tolerate true publication businesses in Nepal. Nor were mail order businesses of the popular money-making type being run at the time in Benares allowed. It was only during Juddha Shamsher's period of rule (1932-45) that a comparatively liberal atmosphere for publishing and scholarly practice arose in Nepal. It is notable that the Sanskrit scholar and royal priest of the Rana palace Hemraj Sharma, who had very good relations with Chandra Shamsher, was exiled from Nepal after the latter's death in November 1929, and remained outside the country during the rule of Bhim Shamsher. He lived in Calcutta for almost two years and came back only after Bhim Shamsher's death in 1932, when he was called back by the new prime minister, Juddha Shamsher. ${ }^{48}$ The latter realized Nepalis' interest in publications and allowed two periodicals, $S \bar{a}$ radā (monthly from v.s. 1991 on) and Udyog (fortnightly from v.s. 1992 on), to circulate. He also provided yearly nine hundred rupees in financial support to these periodicals. Later Sāhitya srot (estab. v.s. 2002) and $\tilde{A} k h \bar{a}$ (estab.

people were the main reasons for the demise of Gorkhālī; see Pratīkshā, "Mādhyamik kālko patrapatrikāko itihās," 807. 
v.s. 2005) received similar financial aid. But these two periodicals did not survive beyond 1951. Likewise, several books were published with funds from the government for printing in India. A Nepali translation of the Bhagavadgita by Komal Nath Adhikari was brought out in v.s. 1990.49 Kulachandra Gautam published his own Sanskrit poetry (with a Nepali translation), Prapañca carcā, in v.s. 1993 in Benares with financial help from Juddha Shamsher. ${ }^{50}$ In October/November 1934 the royal priest Hemraj Sharma brought out an edited version of the Kaśyapa saṃhita (with a detailed foreword) with the Nirnaya Sagar Press, Calcutta.

The censorship of imported published books was very strict during the Rana regime in Nepal. Religious and other popular works in Sanskrit did not have great difficulty in getting printed, imported and read. In other words, texts that had been kept alive with the help of the scribal tradition faced no hurdles to publication, enjoying the nihil obstat of centuries. Books in the Nepali language or otherwise newly created, on the other hand, underwent strict censorship. This was the reason Nepali print entrepreneurs both in and outside Nepal invested their time and capital on the former publications, leaving scholarly or literary works in the vernacular to flounder.

The Rana government provided a trickle of financial support for specific publications and kept close tabs on Nepali writers, print entrepreneurs and books that were going to press in or being imported into Nepal. Given the censorship imposed before financial assistance and permission to publish were granted, Balkrishna Sama, even though a member of the Rana family, still faced difficulties much later in the publication of his first book, Muțiko vyathā (1929). He had to sell some of his wife's jewellery and send his manuscript to Benares for printing. ${ }^{51}$ An example of the Rana government's strict censorship can also be seen in a notice published in the Nepali government newspaper, Gorkhapatra, ordering readers not to subscribe to such Indian magazines as Bande mataram, Jugantar, Sandhya or India. ${ }^{52}$ One other example of such censorship was the ban on importing the political writings of Rahul Sankrityayan, while letting

49 Komal Nath Adhikari, Komal Gīta (Kathmandu: Gorkha Bhasha Prakashini Samiti, 1990 v.s.).

50 The words "yaskā prāyojak śrī tīn mahārājko jaya" (May the Prime Minister, its sponsor, live long!) appear in the foreword of the v.s. 1993 publication; cf. Kulacandra Gautam, Ke pharak bhaecha? (Kathmandu: Kulachandra Gautam Smriti Sanstha, 2070 v.s.), xi.

51 Balakrishna Sama, Mero kavitāko ārādhanā (Kathmandu: Sajha Prakashan, 2054 V.s.), 292.

52 '[F]rom now on no one will subscribe to 'Bande mataram', 'Jugantar', 'Sandhya', or 'India' (published from Lahore) in which news and views against Hind Sarkar (British India Govt.) are published. Every Hindustani and Bengalis who are in service in Nepal are warned that if they have or do any contact with any persons who are against Hind Sarkar would be, as per our wish, expelled from our service and country." (Gorkhapatra v.s. 1964, Shrawan 7; cited in translation in Shrestha, Kashi Bahadur Shrestha, 6o). 
his Buddhist and other philosophical works onto the Nepali market. ${ }^{53}$ The fact that writing in Nepali was monitored by the rulers in Nepal was a stimulus for Nepalis in India to write in Hindi. From 1930 to 1935 Kashi Bahadur Shrestha mostly wrote in that language. ${ }^{54}$ The arm of the Ranas was long, however, so that not only Nepalis living in Nepal but also ones living in India risked repercussions if they patronized him. Not even literary journals were spared. ${ }^{55}$ One may also recall Ram Mani Acharya Dixit being summoned back to Nepal, which resulted in the closure of the Prabhakari Company and Madhavi to cease being published.

There was another opinion in the period regarding the reasons for the small number of Nepali language publications: according to Krishna Chandra Aryal and Baijanath Joshi, ${ }^{56}$ the absence of a book-reading culture among Nepali speakers, which acted as a damper on the Nepali language. The number of books sold was sometimes so weak that publishers became disheartened, and this affected authors as well. In the long run the language itself could not flower under such conditions. Part of the disenchantment had to do with the fact that the few readers that there were preferred reading highly erotic (ati-śringār) literature or other forms that were thought to have a corrosive effect on society and religion (samāj-dharma-dūșak). Moreover, most readers preferred reading Hindi and English books when possible. To get people to read more, publishers suggested that readers buy books themselves, encourage others to do the same, lend books they owned and establish (or encourage the establishment of) libraries.

\section{Market Competition and Copyright Issues among Print Entrepreneurs}

The first Indian Copyright Act was passed in 1847, and the Press and Registration of Books Act of 1867 went on to define more clearly the rights of writers and publishers. Under the pressure of market competition, however, Nepali print entrepreneurs paid neither of them much regard. They had, that is, few qualms about making changes, however minor, to titles and texts.

53 Chudal, A Freethinking Cultural Nationalist.

54 Shrestha, Kashi Bahadur Shrestha, 22.

55 Kashi Bahadur Shrestha, the editor of Udaya, received a warning letter from Nepal's home affairs ministry not to publish political articles in the magazine. He was even criticized by well-wishers for printing a photo of King Tribhuvan in Udaya, even though fully aware that the Ranas would not like it.

$5^{6}$ Krishna Chandra Aryal and Baijanath Joshi, Gorkhā bhạșā (Kathmandu: Gorkha Agency Nepal, 1917), 15-17. 
Religious texts, moral tales, adventure stories and erotic narratives were the most popular genres featured in Nepali publications until the 1950s. Religious literature always earned handsome amounts for print entrepreneurs in India in those days, and it attracted many Nepalis to the profession as well. Since religious literature gained easy entry into Nepal, it represented a precious acquisition for the large number of Nepali Hindu pilgrims visiting Benaressomething that rural Nepali audiences, including ones devoted to erotic literature or lahari sahitya, readily consumed. The karmakanda books were especially prized by those Brahmins who helped perform rituals in India and in Nepal.

Lured by the potential market for religious and erotic literature, no publishing company would hesitate to publish what ought to have been copyrighted material under the same title and author or translator but without the latter's consent, and sometimes even without the author's name on it. This can easily be seen in surviving catalogues and collections. For example, we can take Motiram Bhatta's Prahlād bhakti kathā (the story of Prahlād from the Puranas rendered into Nepali verse), which was printed by five publishers within a span of six years. Such examples show that publishers did not trouble themselves to create and print something new, but instead, having seen something become popular in the market, rushed to make slight changes to it and print the result. Writers in most cases did not benefit from such activity, either by being acknowledged or financially rewarded a percentage of the profit after sales.

Bhanubhakta Acharya's Rāmāyaña was the most popular book on the market among Nepalis. We find 44 editions of the work in the British Library printed between 1923 and 1939 by different publishers. Publishers tried many ploys to make their own publications more popular. Subba Homnath Kedarnath added an eighth canto, the "Rāmāśvamedha," 57 and popularized it by requesting readers not to let themselves be cheated of the incomplete work. Another publisher, Punya Prasad Upadhyaya of Mahakali Aushadhalaya, seeing what his rival had done, called in Padma Prasad Upadhyaya to create the "real Rāmāśvamedha" with 1,300 stanzas. ${ }^{58}$ Such tricks could not go on for very long. Subba Homnath Kedarnath filed a case against Padma Prasad for publishing his Rāmāśvamedha and Krṣnacaritra and won it. Later Subba Homnath Kedarnath took out an advertisement in Gorkhāli, a magazine published in Benares: ${ }^{59}$

57 Its 21st edition was published in 1925 .

$5^{8}$ The 1st edition was published in 1920.

59 Kamal Dīkṣit, Yasto pani (Kathmandu: Madan Puraskar Pustakalaya, 2014 v.s.), 100. 
All Nepalis have been reading the Krșnacaritra and Rāmacaritra in their own language devotedly for sustenance and salvation up to the present. But Punya Prasad has published a bogus Rāmāsvamedha and Krșnacaritra, destroying public devotion by giving the impression in the catalogue that they are original versions, when in fact they are bogus. When he learnt of this deceit against innocent members of the public, Pandit Kedarnath filed a case against him. Afterwards Punya Prasad took an oath in court not to print bogus books and circulate them on the market.... We have published this notice to make you aware so that no one can cheat you by selling you a bogus Krṣnacaritra or Rāmāśvamedha.

Devotion slips away when one reads a book that has changes in wording or spelling. When there is an absence of devotion, the recitation of mantras or scripture and the singing of hymns do not result in merit. [...] Vishvanath means Kashi Vishvanath and Jagannath means Thakurdvara's Jagannath. If the same merit is gained by visiting a newly established Vishvanath and Jagannath, no one would spend so much money for the long journey to Kashi or Thakurdvara. It is clear to all honest lovers of religion that the bogus Krșnacaritra and Rāmāśvamedha ruin our minds and the devotion [expressed in] hymns; therefore, the government has also banned such bogus books. We are thus confident that you will spread this news to all innocent members of the public about what a mistake it is to read [such] bogus books. Here [is] the address for ordering genuine books. ${ }^{60}$

6o bhukti mukti dine bhagavānkā juna krṣnacaritra rāmacaritra āphnā bhāṣāmā ājasamma sārā gorkhālīle bhakti pūrvak paḍhi āyāko ho so āphuharūko bhaktibhāv chuțāune punyaprasādale nakalī rāmāśvamedh krșnacaritra chapāì sūcìmā bhane sakal̄ nai ho bhanyā bhān pārī lāțā sudhālāi jhukyāì bikrī gareko dekhī nijakā nāmmā paṇịt kedāranāthale nālis garī, aba uprānta so nakalì kitāba chapāera bikrī garne chaina bhanne nij punyaprasādko sarkārī kacaharīmā kaboliyatko jabānbandī garā̄ die, tesai garī kasaile āphuharūlāi nakalı̄ krșnacaritra rāmāśsvamedh chapāì najhukyāun bhanī yo kurā jāhera garekā haũ.

śabda akșarako tala māthi pareko pustak paḍnāle bhaktibhāv chuțdacha. bhakti bhāv nabhae jap pāṭh bhajan gareko punya mildaina | [...] viśvanāthjī bhannāle kāśīkai viśvanāthjī, jagannāthjī bhannāle țhākuradvārākai jagannāthjī sakkalì devatā țhaharchan. thāpanā garekā nayā jagannāth viśvanāth darśan garnāle uttikai punya hune bhae tetīkā

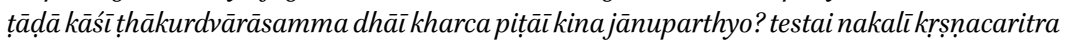
nakalī rāmāśvamedhle hāmīharuko man bigārì bhajanmā bhaktibhāv chuțāune sabai kurā dharmakā premī sajjanaharūlāi jāherai cha tasartha so nakalì kitāb sarkārbātạ pani chapāune manāì bhayāko cha bhanera nakalì kitāb pạ̣hnāle yati kurāko doṣ cha bhanne

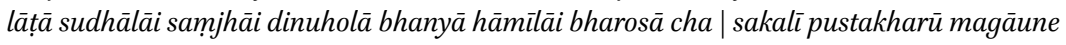
thegānāi. 
Kamal Dīkșit ${ }^{61}$ writes that despite the court order and the oath taken the doctored texts did not stop being published. Publishers continued casting aspersions on each other in a bid to prove that their own production was asali (genuine). They warned readers that ignoring their publication was like accepting glass in place of diamonds and bathing in a dirty pond rather than in the holy river Ganga. Not only religious books but virtually all kinds of books were copied and printed by all entrepreneurs. They did not give a second thought to writers; only the publisher's name was important. Sometimes the writer was mentioned only if he had mentioned his own name as part of a stanza at the end of the poetic creation. A small change in words in the text and wording was enough for publishers to claim it as their own. This unhealthy practice in the publication business among Nepali print entrepreneurs continued on.

\section{Conclusion}

The print entrepreneurs associated with the nascent Nepali print culture in North India were mostly Brahmins who ran print or mail order businesses in Benares. Most of them did not have any previous experience in such businesses before they went to Benares and soaked up the atmosphere there. As learning and paurohitya ('the priesthood') were Brahmins' traditional occupations, this group regarded printing and publication as related fields of endeavour that kept them occupied with books and knowledge. Almost all entrepreneurs were men with a literary background who saw a future in printed books, and these as a means of keeping alive the academic pursuits they had engaged in back home. Many learned this business in Indian publishing houses, there getting on the job training, and later established their own operations.

The newly developing print culture in the Nepali community in the latter half of the 19th century raised new concerns: author-publisher relations, editorial practices, and sales and marketing strategies. We find, for instance, publishers showing keen interest in book fairs to promote lahari sahitya, folk tales, karmakanda, astrological books and, among the religious literature, Nepali bhāvapadyānuvāda. Soldiers in British Gorkha regiments showed particular interest in lahari sahitya, religious writing and such war literature as Jarman laḍāi ko savāī ('A poem on the German war', 1926) by Babu Rajvir Rai.

Whether in India or Nepal, the roots of the Nepali printing business in the private sector lie in religious literature and the mail order business. An important publication house in Nepal, Ratna Pustak Bhandar, was originally

61 Kamal Dīkṣit, Yasto pani (Kathmandu: Madan Puraskar Pustakalaya, 2014 v.s.), 100-105. 
established in 1939 by Ram Das Shrestha as a bookshop, Ram Das \& Sons, which imported religious books from India and sold them locally. Later Ratna Das had some misunderstanding with his father and established his own shop, Ratna Pustak Bhandar, and slowly started publishing on his own. The first book he published was Bhägavat stotra ('Glorification [of Krishna based on] the Bhagavata Purana'), which was followed by an alphabet book in Nepali and Pã̃c stotra ('Five glorifications [of the Lord]'), all very reminiscent of what print entrepreneurs in Benares were doing.

Benares was not the sole city where Nepali publications were produced. Books aspiring to better print quality and backed by greater capital were sent to the Nirnaya Sagar Press in Bombay. In 1869 this press, under Javaji Dadaji began producing the more elegant Bombay font type, whose popularity soon exceeded that of the Devanagari fonts used by other printing presses (Stark 2007: 39). We can judge from the list of books printed by Nirnaya Sagar that it produced big-budget items. Most Nepali books printed by it had the financial backing of Nepal's government; those that did not were usually printed in Benares. ${ }^{62}$

The early printing of Nepali books was constricted by outside circumstances and self-imposed genre limitations. The early Nepali publications introduced Nepal's public to the notion of reading for pleasure rather than merely as something done by Brahmin scholars or priests. It also made people aware of the power of print, of publication as a business, and of writing and involvement in that business as a livelihood and profession. Early printing also encouraged many Nepalis to become literate, which can be seen from the large number of reprints of alphabet textbooks. Nepali religious publications brought knowledge of the sacred Sanskrit texts to the general public at a cheaper price and made it possible for devotional reading to be done in the mother tongue, the language people could understand.

The state of the publishing business in Benares took a new turn with the introduction of technological innovations. It had, of course, previously been a printing hub not only for Nepali but also for Hindi and Sanskrit publications. Eventually, however, Nepali printing shifted to Kathmandu after the restoration of democracy, while the centre of printing in Hindi is now in Delhi. Only the printing of Sanskrit and, more broadly, religious texts is still being carried on in Benares. Very few mail order business entrepreneurs have survived and continue to ship books and other goods to places in India with concentrations of Nepalis and (mainly karmakanda and other religious books) to Nepal.

62 The former included Hemraj Sharma's Kaśyap saṃhitā (1934) and Lekhanath Paudyal's Rituvicār (1917), among others. 
Given the computerization of businesses and traditional printers' unfamiliarity with this process, many older presses have closed down. ${ }^{63}$ However, their importance and that of Benares for the history of Nepali printing cannot be overemphasized.

\section{Bibliography}

Aryal, Krishna Chandra and Baijanath Joshi. Gorkhā bhāṣā. Kathmandu: Gorkha Agency Nepal, 1917.

Bajrācārya, Dhanavajra. Madhyakālkā abhilekh. Kathmandu: Nepāl ra eśiyālī anusandhān kendra, 2056 v.s.

Barāl, Iśvar.Jhyālbātạ. Lalitpur: Sajha Prakashan, 2053 v.s.

Bhaț̣arāi, Ghațrāj. Pratibhaipratibhā ra nepālè săhitya. Kathmandu: Ekata Books, 2051 v.s.

Bhaț̣arāī, Śaradcandra Śarmā, Ramā Śarmā and Śiva Regmī. Motirām Bhaț̣a ra saṃsargī kavi. Kathmandu: Nepāl rājakīya prajñā pratișthān, 206o v.s.

Chalmers, Rhoderick. "Pandits and Pulp Fiction: Popular Publishing and the Birth of Nepali Print Capitalism in Benares." Studies in Nepali History and Society 7, 1 (2002): 35-97.

Chalmers, Rhoderick. "'We Nepalis': Language, Literature and the Formation of a Nepali Public Sphere in India, 1914-1940." Ph.D. thesis, soAs, University of London, 2003.

Chander, Krishna. Encyclopaedic Dictionary of Commerce, vol. 2. Delhi: Sarup \& Sons, 1999 .

Chudal, Alaka Atreya. A Freethinking Cultural Nationalist: A Life History of Rahul Sankrityayan. Delhi: Oxford University Press, 2016.

Cūdāl, Alakā Ātreya, "Nepali sāhityako itihāsmā Kaśī." In Uttarbhāratkonepālēsāhityako itihās, ed. by Alakā Ātreya Cūdāl, In Jagadambā nepālī sāhityako bṛhat itihās, vol. 3, ed. by Mādhav Prasād Pokhrel (Lalitpur: Kamalmani Prakāśan, 2077 v.s.).

Dalmia, Vasudha. "Sanskrit Scholars and Pandits of the Old School: The Benares Sanskrit College and the Constitution of Authority in the Late Nineteenth Century." Journal of Indian Philosophy 24 (1996): 321-37.

Devkota, Grishma Bahadur. Nepālko chāpākhhānā ra patra-patrikāko itihās. Kathmandu: Sajha Prakashan, 2051 v.s.

Dīkṣit, Rāmmaṇi Ācārya. Purānā saṃjhanā, ed. by Keshar Mani Acharya Dixit. Kathamndu: Nalini Devi Acharya Dixit, 2029 v.s.

Dīkṣit, Keśavmaṇi Ā. Śiromaṇi Ācārya Dīkṣit. Kathmandu: Śāntiniketan pustakālaya, 2072 V.s.

Dīkṣit, Kamal. Yasto pani. Kathmandu: Madan Puraskar Pustakalaya, 2014 v.s.

63 Mukesh Publication (personal communication). 
Gaenszle, Martin (in collaboration with Nutan Dhar Sharma). "Nepali Kings and Kāśî: On the Changing Significance of a Sacred Centre." Studies on Nepali History and Society 7, 1 (2002): 1-33.

Gaenszle, Martin, "Nepali Places: Appropriations of Space in Banaras." In Visualising Spaces in Banaras: Images, Maps, and the Practice of Representation, ed. by Martin Gaenszle and Jörg Gengnagel. Wiesbaden: Harrassowitz Verlag, 2006, 303-24.

Gaenszle, Martin. "Emergent Nationalism, Citizenship, and Belonging among Nepalis in Banaras: The Case of Kashi Bahadur Shrestha." In The Politics of Belonging in the Himalayas: Local Attachments and Boundary Dynamics, ed. by Joanna Pfaff-Czarnecka and Gérard Toffin. Governance, Conflict, and Civil Action, vol. 4. New Delhi: SAGE Publications India, 2011, 201-221.

Gautam, Kulacandra. Ke pharak bhaecha? Kathmandu: Kulachandra Gautam Smriti Sanstha, 2070 v.s.

Hutt, Michael. Catalogue of Nepali Printed Books in the Indian Office Library. London: The British Library, 1985 .

Hutt, Michael. Nepali: A National Language and its Literature. New Delhi: Sterling Publication, 1988.

Hutt, Michael and John Whelpton. "The Catalogue of the Hodgson Collection in the British Library." European Bulletin of Himalayan Research 39 (2011): 128-43.

Koirālā, Viśveśvarprasād. Ātmavrttānta. Kathmandu: Jagadambā prakāśan, 2068 v.s.

Nepāl, Jñānmaṇi. "Pṛthvīnārāyaṇlāī sammān kina?" Kāntipur (newspaper article from January 11, 2018). Retrieved November 18, 2019 via https://ekantipur.com/bibidha/2 o18/o1/11/20180111071112.html.

Pāṭhak, Vyākul. Nepālkā viśvakoṣ. Kathmandu: Vidvacchiromaṇi Hemrāj Puraskār guțhī, 2015.

Pradhān, Pārasmaṇi. "Kāśîko nepālī bhāṣā," Vāṇi Sādhanā 2-3, nos. 2-3 (2039-40 v.s.): 2-3.

Pratīkṣā, Sādhanā. "Mādhyamik kālko patrapatrikāko itihās." In Jagadambā nepālī sāhityako brhat itihās: lok sāhitya, prārambhik kāl ra anuvād, vol. 2, ed. by Mādhav Prasad Pokhrel. Lalitpur: Kamalmaṇi prakāśan, 2076 v.s., 787-815.

Rāj, Prakāś A. Vidvacchiromaṇi Hemrāj Śarmā. Lalitpur: Sajha Prakashan, 2057 v.s.

Regmī, Śiva. Nepāli kavitāko bhūmikai bhūmikā. Kathmandu: Nepāl rājakīya prajñā pratișțhān, 2000.

Sama, Balakrishna. Mero kavitāko ārādhanā. Kathmandu: Sajha Prakashan, 2054 v.s. Shrestha, Durga Bahadur. Kashi Bahadur Shrestha. Delhi: Sahitya Akademi, 2003. Śreșțha, Dayārām. "Prārambhik kālko nepālī sāhityako pūrvapīṭhikā." Jagadambā nepālī sāhityako bṛhat itihās: lok sāhitya, prārambhik kāl ra anuvād, vol. 2, ed. by Mādhav Prasad Pokhrel. Lalitpur: Kamalmạ̣i Prakāśan, 2076 v.s., 379-662.

Stark, Ulrike. An Empire of Books: The Novel Kishore Press and the Diffusion of the Private Word in Colonial India. New Delhi: Permanent Black, 2007.

Subedi, Abhi. Sirjanā ra mūlyānikan. Lalitpur: Sajha Prakashan, 2051 v.s. 